\title{
TCF21 wt Allele
}

National Cancer Institute

\section{Source}

National Cancer Institute. TCF21 wt Allele. NCI Thesaurus. Code C54233.

Human TCF21 wild-type allele is located within 6 pter-qter and is approximately $6 \mathrm{~kb}$ in length. This allele, which encodes transcription factor 21 protein, is involved in the regulation of both epithelial differentiation and morphology. 